HYDROLOGIC EFFECTS OF HIGHWAY-DEICING

CHEMICALS IN MASSACHUSETTS--EXECUTIVE SUMMARY

By L. R. Frost, Jr., Samuel J. Pollock, and R. F. Wakelee

U.S. GEOLOGICAL SURVEY

Open-File Report 81-210

Prepared in cooperation with the

MASSACHUSETTS DEPARTMENT OF PUBLIC WORKS

RESEARCH AND MATERIALS SECTION for the

COMMONWEALTH OF MASSACHUSETTS

DEPARTMENT OF PUBLIC WORKS and the

U.S. DEPARTMENT OF TRANSPORTATION

FEDERAL HIGHWAY ADMINISTRATION

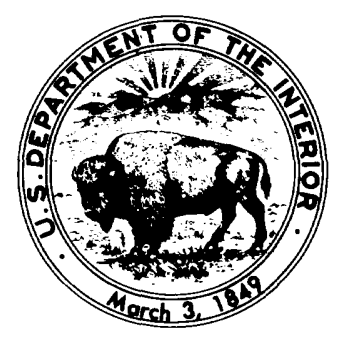




\section{UNITED STATES DEPARTMENT OF THE INTERIOR \\ JAMES G. WATT, Secretary GEOLOGICAL SURVEY}

Doyle G. Frederick, Acting Director

For additional information, write to:

U.S. Geological Survey

150 Causeway Street, Suite 1001

Boston, MA 02114 


\section{CONTENTS}

Abstract -

Introduction -...

Stream-monitoring sites -

Ground-water-monitoring sites-

Chloride budget-...

Summary and conclusions

References cited.-...

\section{ILLUSTRATIONS}

Figure 1. Highway and monitoring locations at the Boulder Bro

\section{TABLES}

Table 1. Regression equations for estimating chloride and sodium concentrations and loads

2. Variables found to be significantly correlated (at the 90 percent confidence level) with chloride concentrations at ground-watermonitoring sites -

3. Chloride and sodium applications to roads and stream loads of chloride and sodium in the Boulder Brook drainage basin near East Bolton,

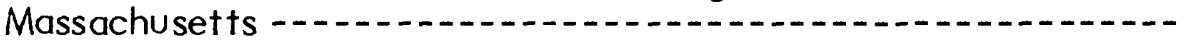

4. Calculated values of ground-water and surface-water chloride loads, Boulder Brook sites -...... 
HYDROLOGIC EFFECTS OF HIGHWAY-DEICING

CHEMICALS IN MASSACHUSETTS--EXECUTIVE SUMMARY

By L. R. Frost, Jr., Samuel J. Pollock, and R. F. Wakelee

\section{ABSTRACT}

Methods of estimating annual mean and annual maximum chloride concentrations and sodium concentrations in streams were developed through multiple and simple linear regression techniques using data collected during the 1972-77 water years. Independent variables are easily obtainable parameters, such as total salt application within a basin, annual precipitation, and drainage basin characteristics. Methods for obtaining gross estimates of chloride loads and sodium loads from salt-application data and estimates of nonhighway-related chloride and sodium were suggested.

A chloride budget was calculated for a small basin draining a section of interstate highway. The chloride budget was described in terms of the percentages in direct runoff to the stream, in ground-water discharges to the stream, in storage in the ground, and the amount unaccounted for.

Attempts were made to relate chloride concentrations in ground water adjacent to highways to quantities of salt applied to the highways on an annual basis, annual precipitation, depth of the wells below land surface, depth of the well below water table, and the distance of the well from the edge of the pavement. Little correlation was observed between annual salt-application values and annual mean chloride concentrations in ground water near highways. The irregular distribution of highway runoff, due to topographic differences between sites, and variations in runoff resulting from individual storms seem to be the causes of the lack of significant correlation between annual quantities of salt applied and chloride concentrations in ground water near highways.

\section{INTRODUCTION}

The policy of the MDPW (Massachusetts Department of Public Works) has been to maintain Massachusetts highways in a "high level of service" condition during the entire year (Massachusetts Department of Public Works, 1976). This "high level of service" condition has been achieved during the winter by application of deicing chemicals, principally sodium chloride, to maintain bare pavement.

Deicing chemicals, however, enter the hydrologic environment, and numerous reports of increasing sodium and chloride concentrations in water supplies have been documented.

The MDPW stated policy is to continue maintaining Massachusetts highways in a "high level of service" condition during the winter and, at the same time, to judiciously reduce or eliminate undesirable effects of these chemicals on the hydrologic environment. To this end, the USGS (U.S. Geological Survey) and MDPW began a cooperative study in January of 1970 to determine the concentrations of highway deicing salt in the hydrologic environment and to develop techniques for estimating these concentrations to allow design of new highways and highway drainage systems to protect adjacent sensitive areas. This study examines the proportion of highway salt transported from the highway by streams and the degree to which ground water is affected by highway runoff near salted roadways.

Three field experiments were designed to (1) determine the total amount of salt leaving drainage basins in streams, (2) determine the quantity of salt entering and moving with ground water near highways, and (3) determine the chloride budget of one site. 


\title{
Stream-Monitoring Sites
}

The discharge of salt from a drainage basin was measured at nine sites selected from a network of over 100 surface-water-gaging stations operated by the U.S. Geological Survey in cooperation with State and other Federal agencies. About 30 of these gaging stations that monitor streamflow from small drainage areas were evaluated to determine their suitability as sites for recording salt discharge from the basin. Criteria for selecting a site to monitor included: (1) that highways are located in the basin, (2) that the amount of salt applied could be determined, and (3) that there be little interference from sources of salt other than highway deicing chemicals.

All but 11 of the 30 sites were rejected, principally because urbanization within the basins was indicative of potential sources of salt other than highway deicing chemicals. Of the 11 remaining sites, two were rejected because salt-storage piles were located upstream. The nine sites selected for instrumentation and study are listed below.

\author{
U.S. Geological Survey \\ station name and location
}

U.S. Geological

Survey station

number

$\begin{array}{ll}\text { South Branch Ashuelot River at Webb, near Marlborough, New Hampshire } & 01160000 \\ \text { Beaver Brook at Wilmington, Vermont } & 01167800 \\ \text { Boulder Brook near East Bolton, Massachusetts (upstream gage) } & 01096906 \\ \text { Boulder Brook at East Bolton, Massachusetts (downstream gage) } & 01096910 \\ \text { Browns Brook near Webster, Massachusetts } & 01124750 \\ \text { Hop Brook near New Salem, Massachusetts } & 01174000 \\ \text { Moose Brook near Barre, Massachusetts } & 01173260 \\ \text { Nashoba Brook near Acton, Massachusetts } & 01097300 \\ \text { Walker Brook near Becket Center, Massachusetts } & 01180800\end{array}$

The stream-monitoring experiment was designed to determine the quantity of salt leaving the drainage basins in streams and to relate this to the quantity of highway salt applied, to precipitation on the basin, and to basin characteristics. In this analysis, it is assumed that salt entering both surface-water and ground-water bodies in the basin ultimately leaves the basin in streamflow.

Equations converting daily mean specific conductance to estimates of daily sodium concentrations and chloride concentrations were derived by relating laboratory specific-conductance values to laboratory sodium concentrations and chloride concentrations, respectively, through regression techniques. These daily concentrations were used with streamflow data to compute daily chloride and sodium loads (tons) from which total amount of salt leaving the basins in streamflow was estimated. Equations (table I) were developed to estimate sodium and chloride loads and concentrations from easily obtainable data. Records of salt application were obtained from MDPW, precipitation data from records of the National Oceanic and Atmospheric Administration (1971-77), and drainage-basin character istics from a report by Wandle (1977).

\section{Ground-Water Monitoring Sites}

Regression equations for estimating chloride concentrations in ground water were obtained for seven ground-water-monitoring sites using correlation techniques to identify the significant variables that influence the entry and movement of highway runoff in ground water and then using the significant variables in multiple-regression analyses. Correlations between the potential variables (table 2) that influence entry and movement of highway runoff in ground water show that the significant variables include SCRNBLWL (all seven sites), DEPTHBLS (four sites), DISTANCE (two sites), and SALTAPPL (one site). 
Table 1.--Regression equations for estimating chloride and sodium concentrations and loads

$$
\begin{aligned}
& \text { MEAN_CL }=-0.94+1.22 \times \frac{\text { SALT_APP }}{\text { ANAVFLOW }}+0.06 \text { SLOPE } \\
& R=0.91 \quad S E 3.3 \mathrm{mg} / \mathrm{L} \\
& \text { MAX_CL }=26.1+2.1 \times \frac{\text { SALT_APP }}{\text { ANAVFLOW }}-3.2 \times \text { STORAGE } \\
& R=0.76 \quad S E=12 \mathrm{mg} / \mathrm{L} \\
& C L \_L O A D=-37.8=50.0 \text { STORAGE }+0.816 \text { SALT_APP } \\
& R=0.93 \quad S E=90 \text { tons } \\
& \text { MEAN_NA }=5.13+0.483 \times \text { CONCSALT } \\
& R=0.90 \quad S E=1.9 \mathrm{mg} / \mathrm{L} \\
& \text { MAX_NA }=11.0+1.02 \times \text { CONCSALT } \\
& R=0.90 \quad S E=4.0 \mathrm{mg} / \mathrm{L} \\
& \text { NA_LOAD }=-36.4+14.9 \text { STORAGE }+1.02 \text { SALT_APP } \\
& R=0.98 \quad S E=26 \text { tons }
\end{aligned}
$$

where:

$R$

SE

MEAN CL

$M A X \bar{C} L$

CLLOAD

(tōns/day)

MEAN NA

$M A X \bar{N} A$

NA LOAD

SALT APP

SLOPE

STORAGE

ANAVFLOW CONCSALT
Multiple correlation coefficient.

Standard error of estimate.

Annual average of daily mean chloride concentrations ( $\mathrm{mg} / \mathrm{L}$ ).

Annual maximum of daily mean chloride concentrations (mg/L).

Annual sum of daily values of chloride concentrations $(\mathrm{mg} / \mathrm{L}) \times$ discharge $(\mathrm{ft} / \mathrm{s}) \times 0.0027$.

Annual average of daily mean sodium concentrations $(\mathrm{mg} / \mathrm{L})$.

Annual maximum of daily mean sodium concentrations $(\mathrm{mg} / \mathrm{L})$.

Annual sum of daily values of sodium concentration $(\mathrm{mg} / \mathrm{L}) \times$ discharge (tons/day) $\left(\mathrm{ft}^{3} / \mathrm{s}\right) \times 0.0027$

Annual sum of tons of chloride applied to roadways in the basin.

Slope of main channel, in feet per mile, between points 10 percent and 85 percent along the stream from monitoring site to the topographic divide.

Area of lakes and ponds expressed as a percentage of the drainage area plus 0.5 percent.

Annual mean rate of water discharge $\left(\mathrm{ft}^{3} / \mathrm{s}\right)$.

SALT_APP divided by ANAVFLOW. 
Table 2.--Variables found to be significantly correlated (at the 90 percent confidence level) with chloride concentrations at ground-water-monitoring sites

(Monitoring sites: $A=A l l$ sites; $B=$ Andover; $C=$ Wayland; $D=$ Chelmsford; $E=$ Needham; $F=$ Canton; $G=$ Bolton; $H=$ West Newbury.)

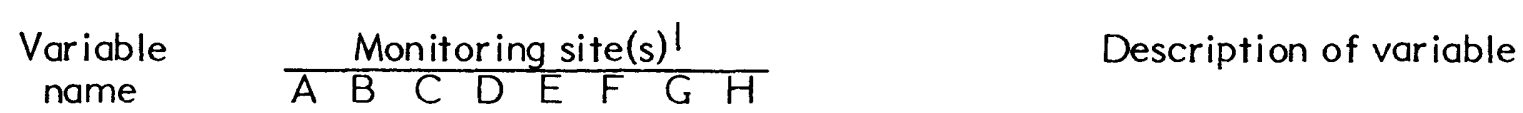

SALTAPPL $M \quad X$

DECMRPPT

PRECIP

DELPPT

DISTANCE $\quad M \quad X$

DEPTHBLS $\times \times \quad \times \times$

ALTLAND

$\begin{array}{lllllllllll}\mathrm{O} & \mathrm{O} & \mathrm{O} & \mathrm{O}\end{array}$

$\mathrm{O}$

AVWTRLVL

$\mathrm{O}$

O $\mathrm{O}$

SCREENAT

$0 \quad 0 \quad 0$

$0 \quad 0$

SCRNBLWL $\times \times \times \times$ $\times \times \times$

ANNLSALT $\quad X$

M
Salt application, in tons of sodium chloride per road mile (one side of divided highway).

Precipitation, in inches, during the December through March period for each site.

Annual precipitation, in inches, for each site.

Difference between DECMRPPT and PRECIP.

Horizontal distance of a well from the edge of pavement.

$X$ Vertical distance of between the land surface and the bottom of the screened intervals in the well.

Altitude of land surface (feet above sea level).

Altitude of annual mean water level (feet above sea level).

Altitude of the bottom of the well screen (feet above sea level).

Vertical distance between the mean water level altitude and the bottom of the well screen.

Annual salt application (SALTAPPL) divided by PRECIP.

${ }^{\prime} M=$ marginal statistical significance; $O=$ statistically but not hydrologically significant; $X=$ hydrologically and statistically significant.

Poor correlation between CHLORIDE and ANNLSALT may be due to differences in overland movement of the highway runoff, in geology, location of the screens of selected wells in the ground-water-flow system, or differences in infiltration characteristics of the roadside soil.

A two-dimensional solute transport model for ground water was calibrated using data from one site. Model results indicated that variations in the distribution of highway runoff, probably caused by topographic differences, was the dominant factor in variations of chloride concentrations in ground water at this site. 


\section{Chloride Budget}

Boulder Brook near East Bolton (fig. 1), was instrumented to measure the chloride content of ground water and chloride and sodium discharge in streamflow. The basin had a drainage area of 1.54 square miles and a bedrock channel near the downstream measuring site which minimized ground-water underflow.

A comparison between chloride and sodium applied to roadways upstream from each of two monitoring sites and chloride and sodium loads in streamflow at the two monitoring sites are listed in table 3. Percentages of applied chloride and sodium appearing in stream discharge are included.

Table 3.--Chloride and sodium applications to roads and stream loads of chloride and sodium in the Boulder Brook drainage basin near East Bolton, Massachusetts

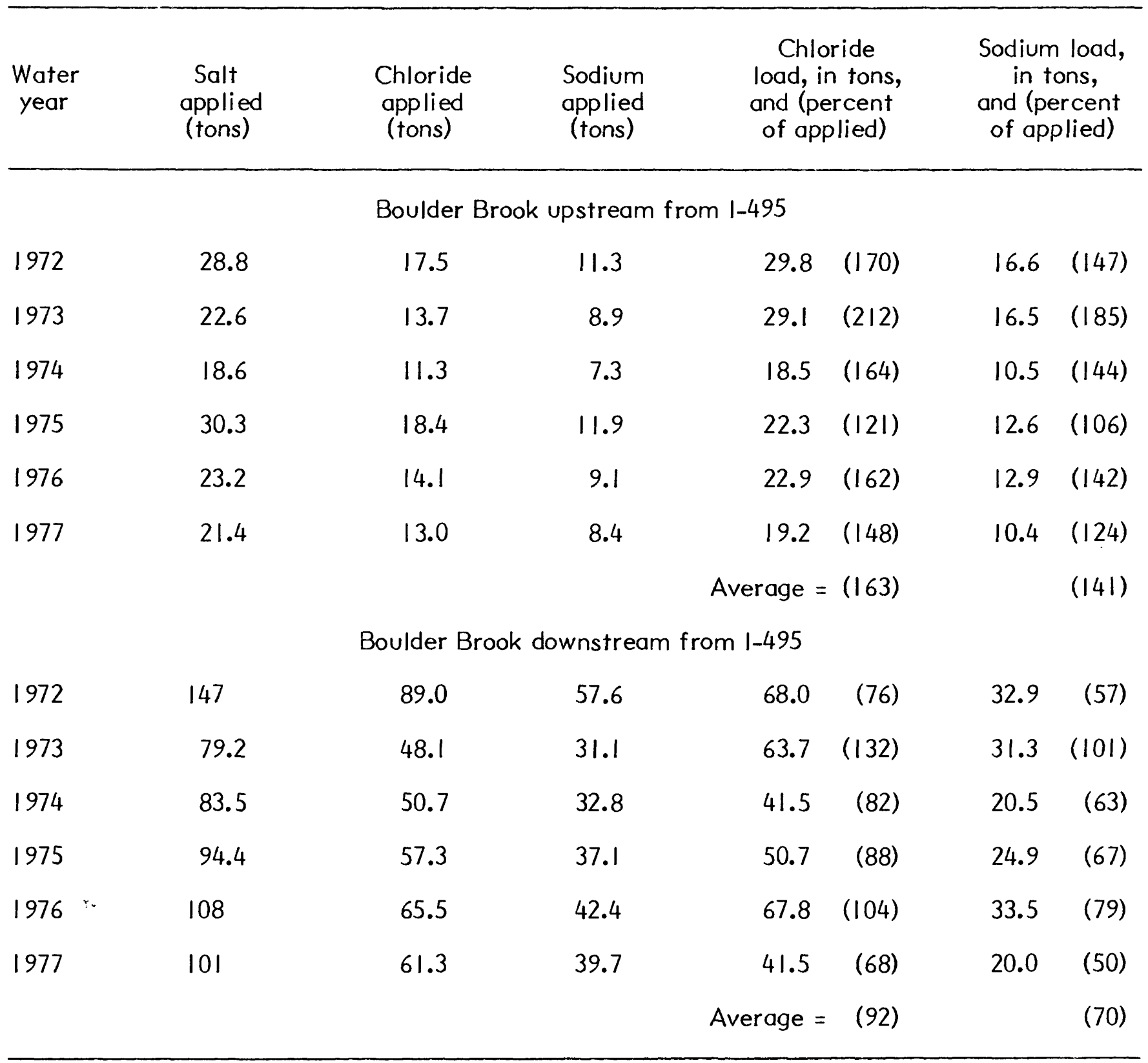




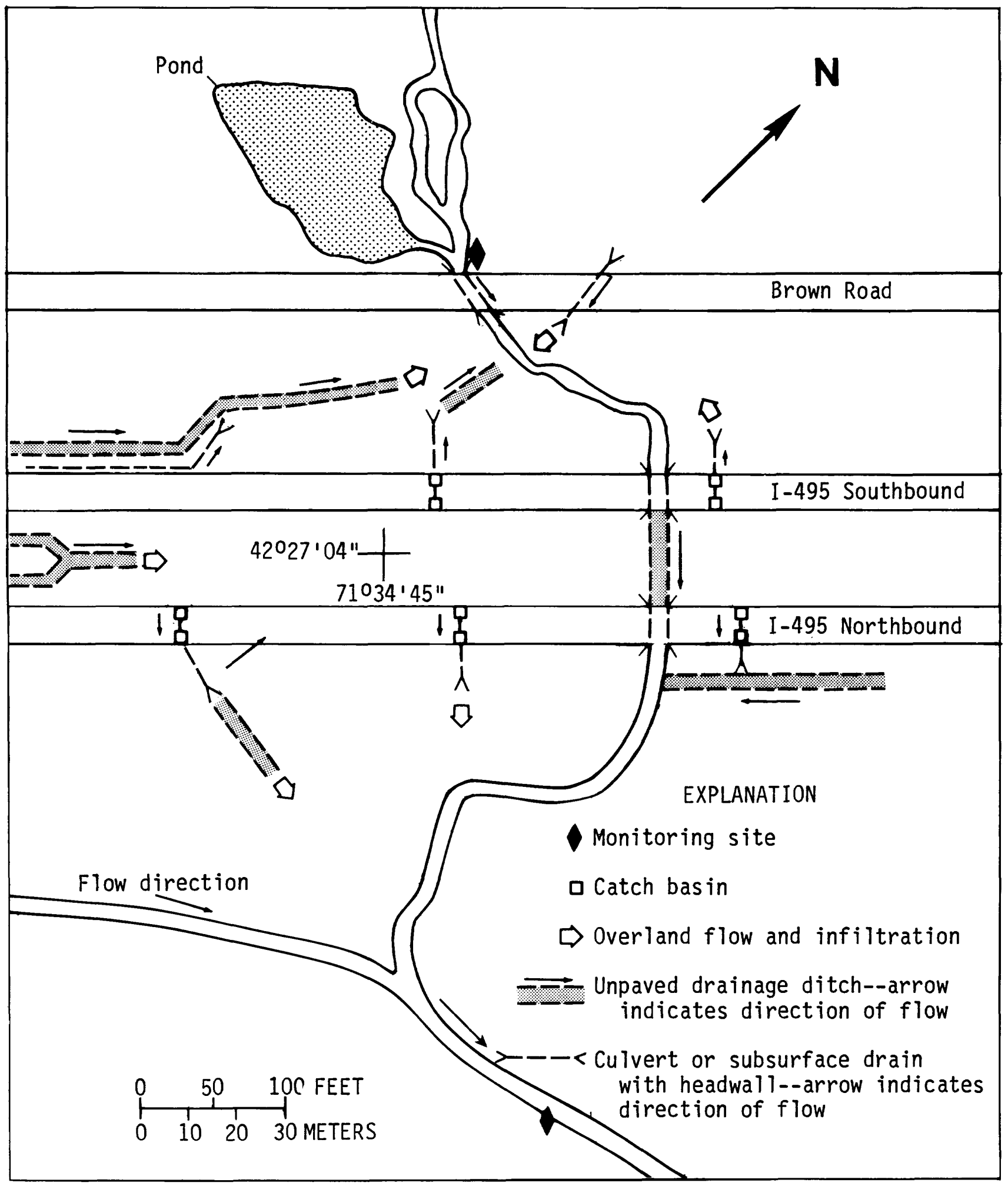

Figure 1.--Highway and monitoring locations at the Boulder Brook site 
Stream hydrograph separation was used to distinguish ground-water chloride discharges from the chloride in direct runoff. The results (table 4) indicate that a large part of the chloride applied entered the ground-water system.

Table 4.-Calculated values of ground water and surface water chloride loads, Boulder Brook sites

Water year

1972

1973

1974

$1975 \quad 1976$

Chloride load at downstream monitor

68.0

$63.7 \quad 41.5$

50.7

67.8

Chloride load at upstream monitor

29.8

29.1

18.5

22.3

22.9

Chloride load from the lower basin

$38.2 \quad 34.6$

23.0

28.4

44.9

Ground-water-chloride load from the lower basin

21.6

26.2

18.4

23.2

32.1

Surface-water-chloride load from the lower basin

16.6

8.4

4.6

5.2

12.8

Chloride applied in lower basin

71.5

34.4

39.4

38.9

51.4

Percentage of applied chloride entering stream

as over land runoff

$23 \quad 24$

12

13

25

The calculation of a chloride budget for Boulder Brook based on salt applied to 1-495 and town roads between the two stream-monitoring sites is as follows:

\begin{tabular}{|c|c|c|c|c|c|}
\hline $\begin{array}{l}\text { Water } \\
\text { year }\end{array}$ & $\begin{array}{l}\text { Chloride } \\
\text { applied } \\
\text { (tons) }\end{array}$ & $\begin{array}{l}\text { Direct runoff } \\
\text { component of } \\
\text { stream chlo- } \\
\text { ride load } \\
\text { (tons) }\end{array}$ & $\begin{array}{l}\text { Ground-water- } \\
\text { discharge } \\
\text { component } \\
\text { of stream } \\
\text { chloride load } \\
\text { (tons) }\end{array}$ & $\begin{array}{l}\text { Change in } \\
\text { chloride } \\
\text { stored in } \\
\text { ground } \\
\text { water } \\
\text { (tons) }\end{array}$ & $\begin{array}{c}\text { Applied } \\
\text { chloride } \\
\text { not } \\
\text { accounted } \\
\text { for } \\
\text { (tons) }\end{array}$ \\
\hline 1972 & 71.5 & 16.6 & 21.6 & +8.8 & 24.5 \\
\hline 1973 & 34.4 & 8.4 & 26.2 & -6.4 & 6.2 \\
\hline 1974 & 39.4 & 4.6 & 18.4 & -5.6 & 22.0 \\
\hline 1975 & 38.9 & 5.2 & 23.2 & +6.8 & 3.7 \\
\hline 1976 & 51.4 & 12.8 & 32.1 & +7.2 & -.7 \\
\hline Total & 235.6 & 47.6 & 121.5 & 10.8 & 55.7 \\
\hline
\end{tabular}

IChange from beginning to end of water year.

Approximately 24 percent of chloride applied as highway deicing chemicals was not accounted for in the budget. Calculations of chloride stored in the ground water and in the amount applied to $1-495$ are the most probable discrepancies in the chloride budget. 
Annual mean chloride concentrations and annual mean sodium concentrations were calculated through the relations between chloride concentration and specific conductance and between sodium concentration and specific conductance. Multiple-regression analyses were done and relations obtained, from which values of annual mean chloride concentrations and annual mean sodium concentrations can be estimated.

Equations for estimating maximum daily concentrations of chloride and sodium were obtained in a similar manner.

The effect of application of sodium chloride as a deicing chemical is well accounted for in the relations between sodium concentrations and salt application and chloride concentrations and salt application. However, chloride loads for all stream-monitoring sites ranged from 68 percent to 660 percent of applied chloride.

A range of prehighway deicing concentrations of sodium chloride indicated by salt-application data and loads calculated during this study would be between 5 and $10 \mathrm{mg} / \mathrm{L}$.

Approximately 52 percent of the chloride applied to $1-495$ and some town roads between the monitoring sites on Boulder Brook (budget site) entered the stream from the ground-water system. Approximately 20 percent of the applied chloride entered the stream as surface runoff, and about 5 percent was accounted for by the net change in chloride stored in the aquifer. The remaining 24 percent of chloride applied to the road's between the monitoring sites was not accounted for in the calculations. Based on the proportions of sodium and chloride in salt applied to the roadways, the discharge of chloride and sodium in streamflow, and the application of a small but not accurately determined quantity of calcium chloride, the amount of sodium retained in the soil was estimated to be 20 percent of the sodium applied.

Relating the concentrations of chloride in ground water near several highway systems to well location, salt application, and precipitation was more difficult than anticipated at the onset of this study. The development of regression equations from which accurate estimates of chloride concentrations could be made was complicated by the following conditions:

(1) Salt application-data not specific to section of roadway near monitoring wells. Averages were used that represented many miles of roadway which included a variety of road-surface conditions such as hills, flat stretches of roadway, ramps, curves, and interchanges; whereas, the monitoring site represented only one of these situations, generally the flat, straight stretches.

(2) Salt application by different maintenance sections. In some places, crews from different maintenence sections salted the same stretches of roadway, resulting in some uncertainty with respect to quantities of salt spread on the stretch of roadway.

(3) Salt application by towns not well accounted for. Some of the data obtained from towns was based on records of purchase rather than records of application. In some circumstances, the amount purchased had to be reconstructed from the town highway superintendent's memory and from fiscal data.

(4) Initial assumptions based on too few data. Well locations were chosen based on previous small-scale investigations during which data indicated that salt entering the ground from highway runoff did so within 15 feet of the highway. Indications from this study are that highway runoff is widely dispersed in the vicinity of the edge of the highway, influenced, at least partly, by the topography adjacent to the highway. Apparently, some of the snow-salt mixture plowed from the highway surface escapes the drainage system; whereas, some of the snow and ice melting on the road surface do not, causing the distribution of salty runoff to be variable.

(5) Consistency of chemical analyses. Throughout this project, the equipment and reagents used to determine chloride concentrations varied. The personnel assigned to the analysis of samples were of varied backgrounds, and included inexperienced temporary personnel as well as chemists. The extent of analytical differences arising from differences in skill 
of personnel assigned to this task is not known. During the first few years of data collection, many repeats of analysis were requested, sometimes resulting in greatly differing analytical values. However, improved quality-assurance practices established by the laboratory resulted in accurate, reproducible values during the final years of the study.

(6) Quantity of data available for analysis. The planned network of wells was completed in the early to middle part of the 1974 water year. Much of the data analysis was based on annual averages and only 3 full years of data were available for study of a period common to all sites. The relationships sought could have been obscured by I unusual year in 3 .

(7) Variations in total salt application at some sites may have been insufficient to cause a greater influence on chloride concentrations than caused by the variations in melting and runoff during each salting season.

Despite the limitations represented by the items listed in the foregoing, the regression analyses did indicate that, at nearly all of the ground-water-monitoring sites, the distance of a well from the highway's edge was not a significant factor in determining the chloride concentration in the wells within 100 feet of a highway. Variations in roadside topography are the most probable reason for the lack of correlation between chloride concentrations and distance. This lack of relationship between chloride concentration and distance was supported by attempts to calibrate a two-dimensional solute-transport model for one of the ground-watermonitoring sites. For this site, ground-water recharge had to be assigned chloride concentration values of $100 \mathrm{mg} / \mathrm{L}$, much above the background concentrations (less than 10 $\mathrm{mg} / \mathrm{L}$ ) at distances up to 170 feet from the edge of the roadway in order to make the model reasonably simulate observed data.

In general, values of annual mean chloride concentration, annual mean sodium concentration, annual chloride load, and annual sodium load in streams can be estimated with sufficient reliability to satisfy requirements of most environmental impact statements. Concentrations of chloride in ground water adjacent to (within a few hundred feet of) highways probably cannot be accurately related to salt application by statistical techniques which do not account for the wide variety of surface runoff patterns caused by topography of roadside areas. Nonstructural surface-drainage features such as variations in roadside topography influenced highway deicing chemical distribution in ground water within 300 feet of the highways studied to the extent that the effects of geology, salt application, precipitation, depth of well, and depth to water table could not be related closely to annual average or annual maximum chloride concentration in ground water.

Reasonably accurate chloride concentrations in ground water, as a result of highway deicing, have not been estimated during this study for several reasons, inadequate instrumentation among them. The characteristic of most importance, the distribution of chloride-containing recharge, was not recognized until data analysis was in progress. This characteristic must be adequately described before concentrations of chloride in ground water at any particular point can have much meaning. Thus, if the distribution of chloride-containing runoff from a highway can be described, then wells can be installed to determine the effects of chloride-containing recharge on the ground-water system.

Selecting sites for such study would be crucial and would have to represent highway drainage features. A decision to study highway-deicing impact on areas that have a potential for water supply might make site selection easier. Because future highway design is to accommodate the deicing-chemical problem, sites, ideally, will be selected by joint parties of highway design engineers and hydrologists. Selecting sites mainly on the basis of geology was a weakness of this study. Highway drainage features were not determined until the data-analysis phase and were difficult to categorize.

Ideal sites would be located where highway runoff (that fraction escaping the storm sewers, etc.) is not channeled far from the edge of the roadway by ruts, pathways, or other features not part of the highway design. After selection of sites, wells could be located to represent the general topography. If the edge of the roadway is mostly steeply sloped, wells installed in the steep-sloped part of the site would more nearly categorize the site. The necessity of measuring fluxes of chloride is an important consideration in constructing and 
locating wells. Wells per site could be much fewer than those used in this study and yet yield information more closely related to the quantity of salt applied. The site selected would need to be as close to the roadway as possible but not so close that deicing chemicals could be sprayed or splashed beyond the site. With the wells fully penetrating (from land surface to bedrock) and screened throughout the saturated zone, an average or integrated sample could be collected to represent the entire saturated thickness of materials. Because such wells would integrate throughout the vertical and wells would be located so that the volume of earth materials could be calculated, many of the problems of interpolating or extrapolating concentrations of chloride between or beyond screened intervals would be eliminated. Chloride content of the block (volume of earth materials) could be calculated on a regular basis and the rate of change of chloride contained in the block related to annual salt application.

A critical part of any study of highway-deicing impact on ground-water bodies would be to establish a procedure for strict accounting of salt applied in the future. Reliable data on salt application are necessary before an effective ground-water investigation.

\section{REFERENCES CITED}

National Oceanic and Atmospheric Administration, 197la, Climatological data: October, v. 83, no. 10.

$197 \mathrm{lb}$, Climatological data: November, v. 83, no. 11.

197/c, Climatological data: December, v. 83, no. 12.

1972, Climatological data, annual summary: v. 84 , no. 13.

1973, Climatological data, annual summary: v. 85 , no. 13.

1974, Climatological data, annual summary: v. 86, no. 13.

1975, Climatological data, annual summary: v. 87, no. 13.

1976, Climatological data, annual summary: v. 88, no. 13.

1977, Climatological data, annual summary: v. 89, no. 13.

Wandle, S. W., 1977, Estimating the magnitude and frequency of floods on natural-flow streams in Massachusetts: U.S. Geological Survey Water-Resources Investigations 77-39, 26 p. 